\title{
Limitation of bacterial growth by dissolved organic matter in the subarctic Pacific
}

\author{
David L. Kirchman \\ College of Marine Studies, University of Delaware, Lewes, Delaware 19958, USA
}

\begin{abstract}
To determine if dissolved organic matter (DOM) limits biomass production of heterotrophic bacterioplankton in the subarctic Pacific, the effect of various DOM and ammonium additions on bacterial production $\left({ }^{3} \mathrm{H}\right.$-thymidine and ${ }^{14} \mathrm{C}$-leucine incorporation) and bacterial abundance was examined. Addition of dissolved free amino acids (DFAA) consistently stimulated ${ }^{3} \mathrm{H}$-thymidine incorporation from. 31 to $393 \%$ compared with unamended controls. Addition of glucose or glucose plus ammonium sometimes stimulated bacterial production, but the effect was always less than that due to DFAA additions. A mixture of alkylamines either had no effect or stimulated ${ }^{3} \mathrm{H}$-thymidine and ${ }^{14} \mathrm{C}$-leucine incorporation to a lesser extent than the DFAA addition. Bacterial abundance did not vary significantly during incubations, nor were there any differences between treatments, indicating that DFAA additions stimulated the average growth rate of the bacterial assemblage. Bacterial growth appeared to be $\mathrm{C}$ limited, sometimes, since glucose alone stimulated ${ }^{3} \mathrm{H}$-thymidine and ${ }^{14} \mathrm{C}$-leucine in 2 out of 7 experiments. The much greater stimulation of bacterial production by DFAA than by glucose plus ammonium indicated that heterotrophic bacteria in the subarctic Pacific were usually energy-limited.
\end{abstract}

\section{INTRODUCTION}

Biomass production of heterotrophic bacteria in the open ocean depends on the supply of dissolved organic matter (DOM), which ultimately originates from phytoplankton. Cole et al. (1988) recently compiled results from several studies and found a high correlation between bacterial and phytoplankton production. When averaged over different seasons and regions, ca $60 \%$ of the variation in bacterial production was explained by variation in rates of primary production (Cole et al. 1988). Furthermore, the ratio of bacterial production vs primary production did not vary, even at high rates of primary production (Cole et al. 1988). This correlational study suggests that the DOM supply limits the rate of bacterial biomass production in aquatic ecosystems, although some other factor that covaries with primary production, e.g. grazing, may actually be limiting (Cole et al. 1988).

Grazing is another factor that is likely to affect rates of bacterial production since it lowers bacterial abundance (e.g. Wright \& Coffin 1984). (Bacterial production is the product of both bacterial biomass and the growth rate.) The steady-state level of bacterial abundance, however, is not solely determined by the grazing rate (Billen et al. 1980). More importantly, it is not clear how grazing could directly affect bacterial growth rates, apart from contributing to the flux of DOM and inorganic nutrients.

What seems more likely is that the average growth rate of heterotrophic bacterial assemblages is limited by DOM or inorganic nutrients. DOM could provide elements $(\mathrm{C}, \mathrm{N}$, or $\mathrm{P})$ that potentially limit bacterial growth in pelagic ecosystems. Another possibility is that bacterial growth rates are limited by DOM quality, in addition to DOM supply. In particular, growth rates of many bacteria in pure cultures are higher with amino acids than with glucose and ammonium alone (Ingraham et al. 1983), because cells conserve energy by avoiding amino acid biosynthesis (Payne \& Wiebe 1978). Amino acids may be important in regulating bacterial growth rates in pelagic ecosystems because much of the bacterial production (ca $50 \%$ ) is supported by dissolved free amino acids (DFAA) in the subarctic Pacific (Kirchman unpubl.) and in other aquatic environments (Jørgensen et al. 1983, Billen \& Fontigny 1987, Fuhrman 1987, Jørgensen 1987). It is unclear, however, whether amino acids simply supply the $\mathrm{C}$ or $\mathrm{N}$ that actually limits bacterial growth, or whether the rate of amino acid supply itself controls bacterial growth rates.

Marine ecosystems are said to be limited by the 
supply of $N$ (e.g. Howarth 1988), although this generalization may not be universally valid (Martin \& Fitzwater 1988). The subarctic Pacific has high concentrations of inorganic $N$ (Anderson et al. 1977, Wheeler \& Kokkinakis unpubl.) which suggests that this ecosystem is not N-limited. The concentration of nitrate never drops below $6 \mu \mathrm{M}$, and ammonium varies between undetectable $(0.05 \mu \mathrm{M}$ ) and $0.4 \mu \mathrm{M}$ (Wheeler \& Kokkinakis unpubl.). The growth rate of heterotrophic bacteria in these waters, as a consequence, may not be $\mathrm{N}$ limited, because heterotrophic bacteria could use the relatively high amounts of ammonium (Wheeler \& Kirchman 1986). P is probably not limiting bacterial growth because phosphate concentrations are also relatively high in the subarctic Pacific (Anderson et al. 1977). Furthermore, heterotrophic bacteria appear to have a greater affinity for both phosphate and ammonium than phytoplankton (Currie \& Kalff 1984, Suttle et al. in press). This presumed lack of $\mathrm{N}$ - and Plimitation suggests that bacteria in the subarctic Pacific are C-limited. In fact, ammonium uptake by heterotrophic bacteria in these waters appears to be limited by the supply of organic C (Kirchman et al. in press), although whether or not bacterial growth rates are Climited has not been demonstrated.

One approach for examining limitation is to measure how bacterial growth changes in response to the addition of various compounds. Studies in both freshwater (Meyer et al. 1987, Gardner et al. 1989) and marine systems (Sieracki \& Sieburth 1985, Wheeler \& Kirchman 1986) have examined how DOM additions affect net changes in bacterial abundance. These studies indicate the importance of DOM in controlling bacterial growth. It is still unclear, however, what exactly limits bacterial growth rates in aquatic ecosystems, because none of these previous studies measured bacterial production, nor were they able to distinguish adequately how DOM controls bacterial growth, e.g. C- vs Nlimitation.

The purpose of this study was to determine which factor limits bacterial growth in the oceanic subarctic Pacific. The overall goal was to examine the role of heterotrophic bacteria in the $\mathrm{N}$ budget of these waters as part of the NSF-supported SUPER project (Subarctic Pacific Ecosystem Research). The main result of this study was that the addition of DFAA was the most effective treatment in stimulating the average growth rate of the bacterial assemblage.

\section{MATERIALS AND METHODS}

Experiments were conducted in September 1987. and May and August 1988 at Stns $P\left(145^{\circ} \mathrm{W} ; 50^{\circ} \mathrm{N}\right)$ and $\mathrm{R}\left(145^{\circ} ; 53^{\circ} \mathrm{N}\right)$, Gulf of Alaska. The differences in microbial parameters between these 2 stations are small, and sufficient data are not available to determine if these differences affect how additions stimulated bacterial production. Water from $10 \mathrm{~m}$ was collected in 301 Teflon-lined GoFlo bottles using a Kevlar line. All experiments were conducted in $20 \mathrm{l}$ polyethylene carboys incubated on deck at surface seawater temperatures (ca $7^{\circ} \mathrm{C}$ in May, and $12^{\circ} \mathrm{C}$ in August and September) and surface light conditions.

The basic experiment consisted of measuring ${ }^{3} \mathrm{H}$ thymidine and ${ }^{14} \mathrm{C}$-leucine incorporation and bacterial abundance over time after the addition of DOM compounds and ammonium to carboys. The added concentration was $0.5 \mu \mathrm{M}$ (final) unless otherwise noted. After addition of compounds, carboys were mixed and the water sampled to measure ${ }^{3} \mathrm{H}$-thymidine and ${ }^{14} \mathrm{C}$ leucine incorporation ( $2 \mathrm{~h}$ incubations; see below) and bacterial abundance (Hobbie et al. 1977). Sampling for rate measurements and abundance was repeated over time (see 'Results'). The DFAA mixture was from the Pierce Chemical Company (catalog number 20088), and contained the common protein amino acids. The alkylamine mixture consisted of di- and tri-methylamine, and putrescine (Sigma), added in equal molar amounts, while the protein was ribulose-1,5-bisphosphate carboxylase (Sigma). This protein was chosen because it is said to be the most abundant protein in nature (Miziorko \& Lorimer 1983).

Incorporation of ${ }^{3} \mathrm{H}$-thymidine and ${ }^{14} \mathrm{C}$-leucine. Incorporation rates of ${ }^{3} \mathrm{H}$-methyl-thymidine $(\mathrm{sp}$. act. $=$ $60 \mu \mathrm{Ci} \mathrm{nmol}{ }^{-1}$; New England Nuclear) (Fuhrman \& Azam 1982) and L- ${ }^{14} \mathrm{C}(\mathrm{U})$-leucine (sp. act. $=0.342 \mu \mathrm{Ci}$ $\mathrm{nmol}^{-1}$; New England Nuclear) (Kirchman et al. 1985) were measured in subsamples removed from the 201 carboys. Each rate estimate was based on 2 subsamples and a control killed with trichloroacetic acid (TCA). Final ${ }^{3} \mathrm{H}$-thymidine and ${ }^{14} \mathrm{C}$-leucine concentrations were 5 and $10 \mathrm{nM}$, respectively. Samples were incubated for 1 to $2 \mathrm{~h}$ at surface seawater temperatures in the dark. After incubation, samples were filtered through $0.45 \mu \mathrm{m}$ Millipore filters, rinsed twice with icecold 5\% TCA, and radioassayed. The dual label approach was used (Chin-Leo \& Kirchman 1988) for experiments in which both ${ }^{3} \mathrm{H}$-thymidine and ${ }^{14} \mathrm{C}$ leucine incorporation are reported.

Bacterial production supported by added amino acids. Bacterial production was calculated from rates of ${ }^{3} \mathrm{H}$-thymidine incorporation using the conversion factor $2.0 \times 10^{18}$ cells mol-1 (Fuhrman \& Azam 1982) and assuming $20 \mathrm{fg} \mathrm{C} \mathrm{cell}^{-1}$ (Lee \& Fuhrman 1987). The ${ }^{3} \mathrm{H}$ thymidine conversion factor was confirmed to be valid for the subarctic Pacific (Kirchman unpubl. data) using the empirical estimation approach (Kirchman et al. 1982). Bacterial production supported by the DFAA addition was estimated by subtracting the control rate 
Table 1. Summary of enrichment experiments. Effect of glucose (Glu) and amino acid (DFAA) additions on ${ }^{3} H$-thymidine incorporation. Stimulation $(\%)=$ (addition rate - control rate $) /$ control rate) $\times 100$; values are means of 2 replicates that differed by $<15 \%$. Final sample from time course experiments (incubations 24 to 56 h) illustrated in figures

\begin{tabular}{|c|c|c|c|c|c|}
\hline Date & $\begin{array}{l}\text { Addition } \\
(\mu \mathrm{M})\end{array}$ & $\begin{array}{c}\text { Control rate } \\
\left(\mathrm{pM} \mathrm{h}^{-1}\right)\end{array}$ & Glu & $\begin{array}{l}\text { Stimulation }(\%) \\
\text { Glu }+\mathrm{NH}_{4}^{+}\end{array}$ & DFAA \\
\hline \multicolumn{6}{|l|}{1987} \\
\hline Sep 30 & 0.25 & 3.50 & ND & ND & 71 \\
\hline \multicolumn{6}{|l|}{1988} \\
\hline May 10 & 0.5 & 0.36 & 0 & 3 & 39 \\
\hline Aug 6 & 0.5 & 7.31 & 0 & 13 & $\begin{array}{c}43 \\
393^{\mathrm{d}}\end{array}$ \\
\hline Aug 14 & 0.5 & 6.94 & 5 & 3 & ND \\
\hline Aug 23 & 0.5 & 5.69 & 0 & 17 & 78 \\
\hline Aug 25 & 0.1 & 1.94 & 19 & 20 & 31 \\
\hline Mean & & & 4.8 & 11 & 52 \\
\hline
\end{tabular}

from the DFAA rate. DFAA uptake was estimated from the decrease in primary amines (see below) assuming the DFAA had an average molecular weight of 116 daltons and was $80 \% \mathrm{C}$. Growth efficiency was calculated by dividing the rate of bacterial production supported by the DFAA addition by the rate of amino acid uptake.

Primary amines. Dissolved primary amine concentrations were measured using o-phthaldialdehyde (OPA; Parsons et al. 1984) and a Turner fluorometer with glycine as the standard. The primary filter cutoff was at $365 \mathrm{~nm}$ (Turner filter \#7-60) and the secondary at $415 \mathrm{~nm}$ (Turner filter \#110-816 or Corning number 2A with a $10 \%$ neutral density filter). Fluorescence due to the reaction of OPA with ammonium was $3 \%$ of glycine fluorescence on a molar basis. This ammonium fluorescence was subtracted from the total fluorescence using independently measured concentrations of ammonium. Kirchman et al. (1989) presents evidence that the primary amine measurement is due, almost entirely, to DFAAs.

\section{RESULTS}

Effect of glucose and DFAA additions on ${ }^{3} \mathrm{H}$-thymidine incorporation and bacterial abundance

To test for possible DOM limitation of bacterial growth, glucose or DFAA was added to water samples and bacterial production $\left({ }^{3} \mathrm{H}\right.$-thymidine and ${ }^{14} \mathrm{C}$ leucine incorporation) and abundance measured over time. Table 1 summarizes results from the final subsamples of all time course experiments, many of which are illustrated in the Figs.

Addition of DFAA and less frequently, glucose, stimulated ${ }^{3} \mathrm{H}$-thymidine incorporation (Table 1). Incor- poration rates were 31 to $71 \%$ higher with DFAA additions compared to controls; the highest stimulation of thymidine incorporation by glucose alone was $19 \%$ (Table 1). In one experiment, described in more detail below, ${ }^{3} \mathrm{H}$-thymidine incorporation in a glucose plus ammonium treatment was 3 -fold higher than the rate when only ammonium was added. When the effects of DFAA and glucose additions were compared in the same experiment, however, DFAA additions always stimulated ${ }^{3} \mathrm{H}$-thymidine production to a greater extent than glucose or glucose plus ammonium (Table 1).

Addition of DFAA and glucose did not stimulate ${ }^{3} \mathrm{H}-$ thymidine incorporation immediately, and the time lag before stimulation was measurable varied from one experiment to the next. In September $1987,{ }^{3} \mathrm{H}$-thymidine incorporation with the DFAA addition was the same as in the control after $1 \mathrm{~d}$, but after $2 \mathrm{~d}{ }^{3} \mathrm{H}$ thymidine incorporation was $50 \%$ higher with the DFAA addition (Fig. 1). In other experiments, stimulation of ${ }^{3} \mathrm{H}$-thymidine by DFAA was observable after $\leq 24 \mathrm{~h}$ incubation (e.g. Fig. 2 and Table 2).

The added concentration necessary to obtain a measurable stimulation in bacterial production also varied. For example, on September 30, a $0.25 \mu \mathrm{M}$ addition of DFAA stimulated ${ }^{3} \mathrm{H}$-thymidine incorporation (Fig. 1); on October 5, a $0.5 \mu \mathrm{M}$ addition of DFAA stimulated ${ }^{3} \mathrm{H}$-thymidine incorporation to a greater degree than a similar addition of glucose (Fig. 2A). In the latter experiment, bacterial abundance was significantly higher in DFAA-amended samples than in either control or glucose-amended samples (Fig. 2B). When $1.0 \mu \mathrm{M}$ was added, bacterial abundance was $26 \%$ higher in DFAA than glucose-amended samples (Fig. 2B). However, this stimulation of bacterial abundance in unfractionated samples was unusual and not observed in other experiments (see below). 


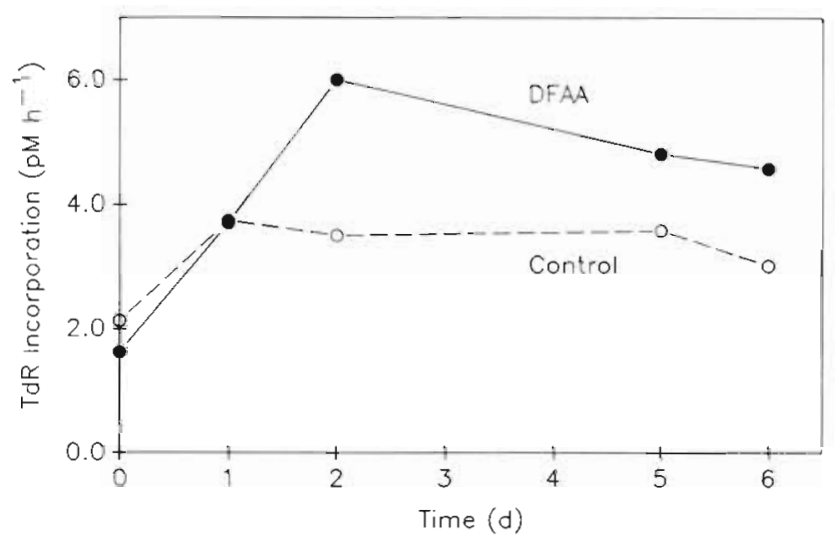

Fig. 1. Effect of dissolved free amino acids (DFAA) addition $\left(0.25 \mu \mathrm{M}\right.$ final concentration) on ${ }^{3} \mathrm{H}$-thymidine (TdR) incorporation. Experiment from September 30,1987 at Stn P. Values are means of 2 replicates that differed by $<15 \%$

\section{Effect of other nitrogenous compounds on bacterial production}

In a series of experiments using organic nitrogen other than DFAA, i.e. protein and alkylamines, only addition of DFAA stimulated ${ }^{3} \mathrm{H}$-thymidine and ${ }^{14} \mathrm{C}$ leucine incorporation. In August 1988, addition of DFAA plus ammonium stimulated ${ }^{3} \mathrm{H}$-thymidine incorporation 3 -fold after $45 \mathrm{~h}$ (Fig. $3 \mathrm{~A}$ ). After $58 \mathrm{~h}{ }^{3} \mathrm{H}$-thymidine incorporation was higher $(43 \%)$ with the addition of DFAA alone compared with unamended controls (Fig. 3A). Addition of ammonium plus DFAA stimulated ${ }^{3} \mathrm{H}$ thymidine more so than did the addition of DFAA alone (Fig. 3A), but this additional stimulation by ammonium was not observed in other experiments (Table 2). Addition of protein, protein plus ammonium, glucose alone, glucose plus ammonium, and ammonium alone all had no effect on ${ }^{3} \mathrm{H}$-thymidine incorporation (Fig. 3A). Also, bacterial abundance did not change significantly during the $58 \mathrm{~h}$ incubation, nor did abundance differ among the various organic additions (Fig. 3B). These results suggest that specifically DFAA additions increase bacterial production ( ${ }^{3} \mathrm{H}$-thymidine incorporation) by stimulating growth rates.

Two experiments indicate that DFAA additions stimulated bacterial production more than alkylamines (Table 2). On August 23, 1988 (48 h incubation), addition of DFAA plus ammonium stimulated ${ }^{3} \mathrm{H}$-thymidine incorporation by $79 \% ;{ }^{14} \mathrm{C}$-leucine incorporation was stimulated by $55 \%$, which is probably an underestimate because of isotope dilution by leucine included with the DFAA addition. In contrast, alkylamine plus ammonium had no significant effect on ${ }^{3} \mathrm{H}$-thymidine and ${ }^{14} \mathrm{C}$-Ieucine incorporation (Table 2). The addition of alkylamines alone stimulated ${ }^{3} \mathrm{H}$-thymidine and ${ }^{14} \mathrm{C}$ leucine incorporation by 22 and $43 \%$, respectively. On
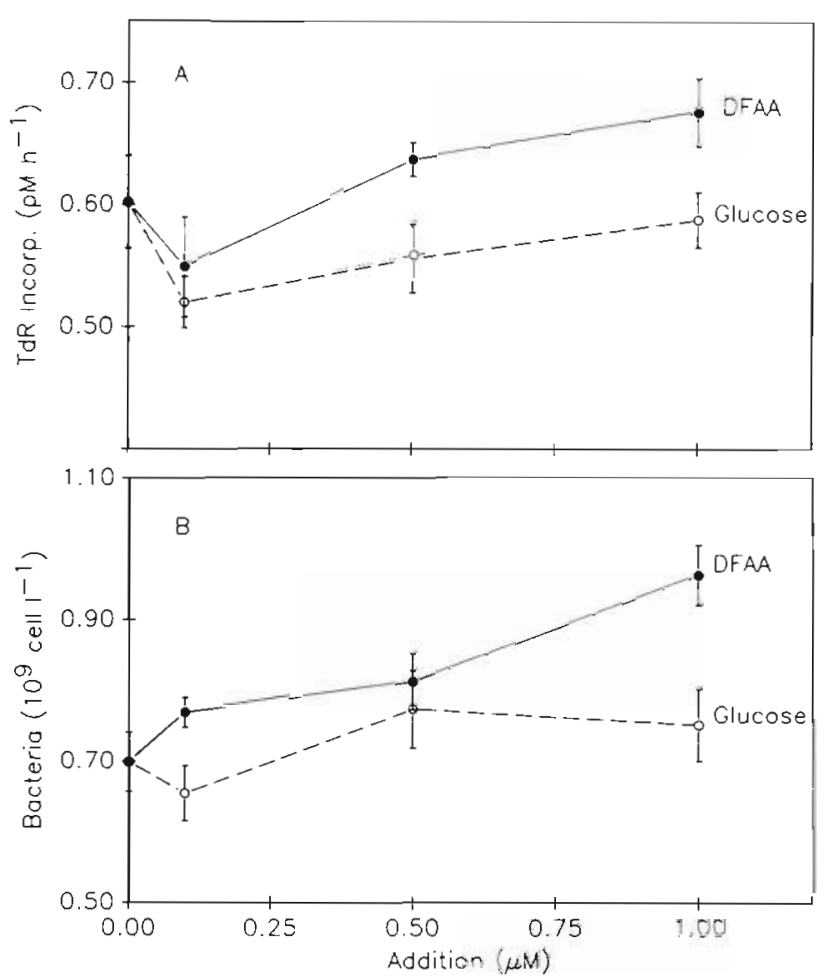

Fig. 2. Effect of amino acids (DFAA) and glucose on ${ }^{3} \mathrm{H}$ thymidine incorporation and bacterial abundance. (A) Incorporation rates of ${ }^{3} \mathrm{H}$-thymidine (TdR) estimated from time course over 24 h (slope $\pm S E$ ); (B) final bacterial abundance ( $\pm S E$ ) after $24 \mathrm{~h}$. Experiment conducted on October 5, 1987 at Stn P

August 27, 1988 (23 h incubation), addition of DFAA stimulated ${ }^{3} \mathrm{H}$-thymidine by $31 \%$, almost twice that observed due to the alkylamine addition (Table 2). In both experiments, bacterial abundance did not change

Table 2. Effect of additions on ${ }^{3} \mathrm{H}$-thymidine $(\mathrm{TdR})$ and ${ }^{14} \mathrm{C}$ leucine (Leu) incorporation. Data from 48 (23 August 1988) and $23 \mathrm{~h} \mathrm{(27}$ August 1988) incubations after $0.25 \mu \mathrm{M}$ additions; values are means of 2 replicates that differed by $<15 \%$. Rates of TdR incorporation were not stimulated before this time for August 23. Same trends were observed for $9 \mathrm{~h}$ samples on 27 August. Bacterial abundance did not change significantly during the entire incubation. Stimulation $\%=$ (addition rate control rate) $/($ control rate $) \times 100$

\begin{tabular}{|c|c|c|c|}
\hline \multirow[t]{3}{*}{ Sample } & \multicolumn{3}{|c|}{ Stimulation $(\%)$} \\
\hline & \multicolumn{2}{|c|}{ Aug 23} & \multirow{2}{*}{$\begin{array}{c}\text { Aug } 27 \\
\text { TdR }\end{array}$} \\
\hline & $\mathrm{TdR}$ & Leu & \\
\hline Control rate $\left(\mathrm{pM} \mathrm{h}^{-1}\right)$ & 5.65 & 36.7 & 1.27 \\
\hline Glucose & -9 & 31 & 19 \\
\hline Alkylamines & 22 & 43 & 17 \\
\hline DFAA & \multicolumn{2}{|c|}{ Samples lost } & 31 \\
\hline Ammonium & 1 & -10 & ND \\
\hline Glucose + ammonium & 17 & 13 & 20 \\
\hline Alkylamines + ammonium & -8 & 1 & ND \\
\hline DFAA + ammonium & 79 & 55 & ND \\
\hline
\end{tabular}



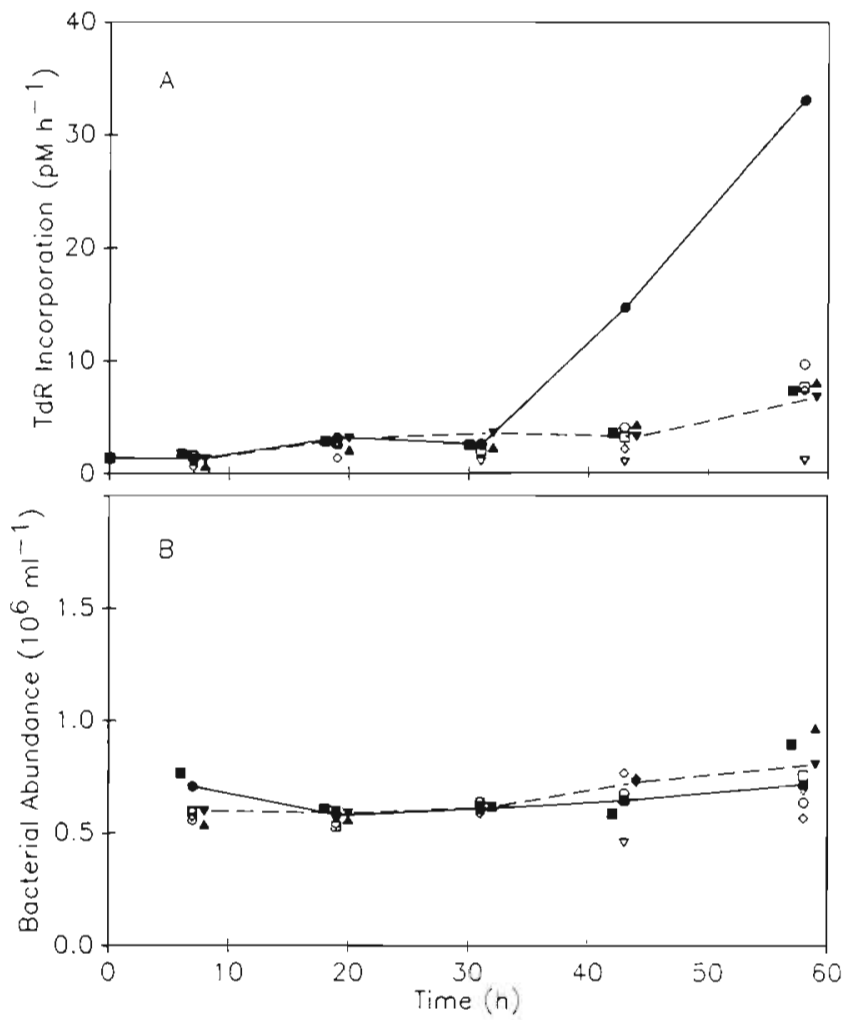

Fig. 3. Effect of additions of various compounds on ${ }^{3} \mathrm{H}$-thymidine (TdR) incorporation (A) and bacterial abundance (B). Compounds are: DFAA $+\mathrm{NH}_{4}^{+}(\bullet \bullet)$, DFAA (o), control $(\mathbf{v - - \nabla})$, protein $(\mathbf{\Delta})$, glucose $(\nabla)$, protein $+\mathrm{NH}_{4}^{+}(\diamond)$, glucose + $\mathrm{NH}_{4}^{+}(\square), \mathrm{NH}_{4}^{+}(\square)$. Final concentration of each $=0.5 \mu \mathrm{M}$. Experiment conducted on August 6,1988 at Stn R. Values are means of 2 replicates that differed by $<15 \%$. Points were offset for clarity

significantly (data not shown). Although the effect of ammonium plus DOM addition is unclear, both experiments confirm that specifically DFAA additions were most effective in stimulating bacterial growth rates.

\section{Effect of glucose on ${ }^{3} \mathrm{H}$-thymidine and ${ }^{14} \mathrm{C}$-leucine incorporation}

In an experiment conducted in May 1988, glucose stimulated ${ }^{3} \mathrm{H}$-thymidine incorporation by $50 \%$ after $11 \mathrm{~h}$, increasing to 3 -fold after $60 \mathrm{~h}$ incubation (Fig. 4A). Similar results were obtained for the $<0.8 \mu \mathrm{m}$ size fraction (results not shown), which contains only the heterotrophic bacterial assemblage, indicating that the glucose addition affected bacteria directly. Also, addition of glucose stimulated ${ }^{14} \mathrm{C}$-leucine incorporation by $50 \%$ after $48 \mathrm{~h}$ and by 6 -fold after $72 \mathrm{~h}$ (Fig. 4B). Bacterial abundance was ca $20 \%$ lower in glucose samples compared with controls near the end of the experiment (Fig. 4C).

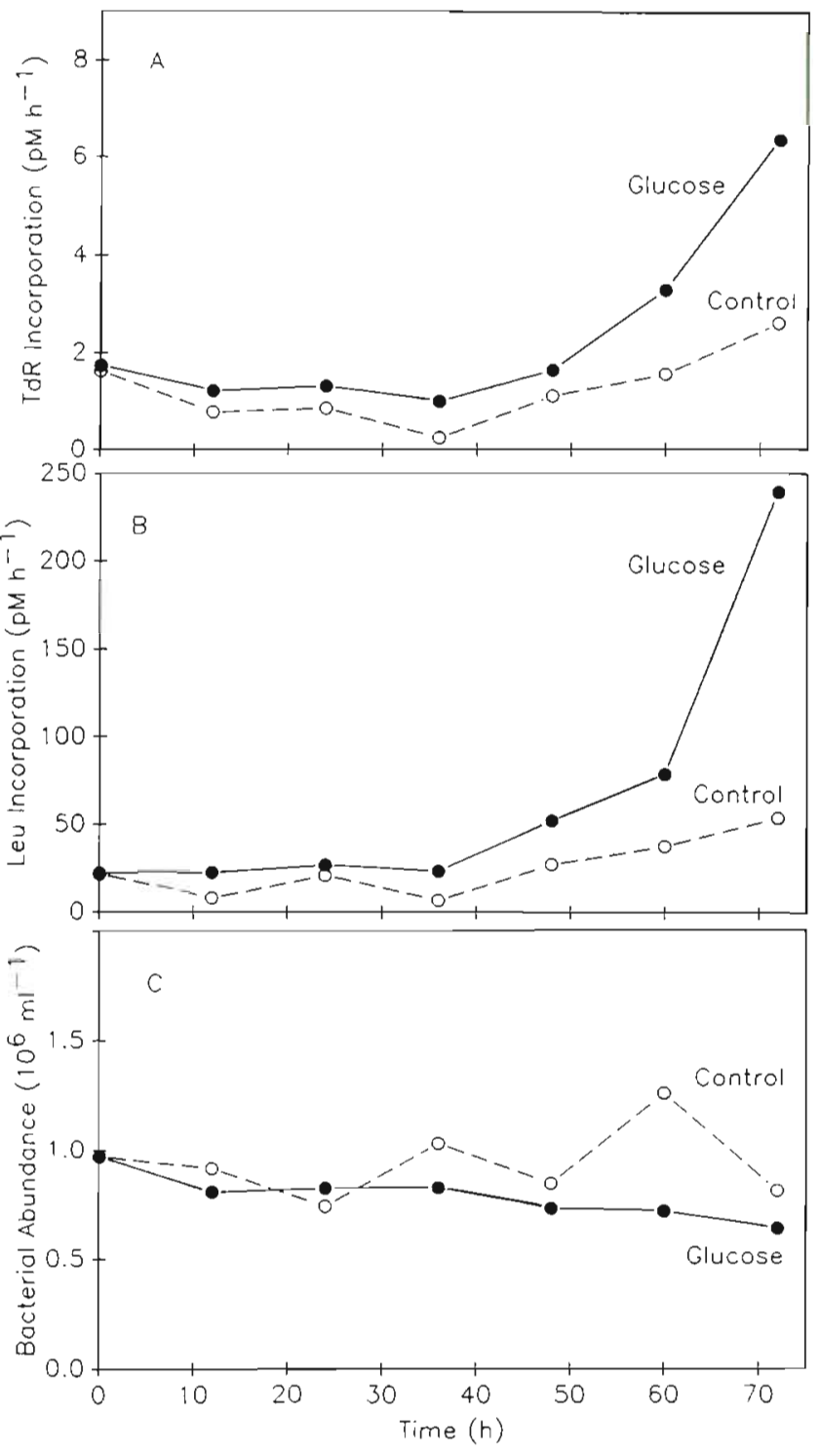

Fig. 4. Response of heterotrophic bacteria after addition of glucose + ammonium (Glucose) or ammonium alone (Control). (A) ${ }^{3} \mathrm{H}$-thymidine incorporation; (B) ${ }^{14} \mathrm{C}$-leucine incorporation; (C) bacterial abundance. Experiment conducted on May 27, 1988 at Stn P. Values are means of 2 replicates that differed by $<15 \%$

\section{Growth efficiency during DFAA utilization}

To determine if the stimulation of bacterial production by the DFAA additions was reasonable and consistent with what is known about DFAA utilization, growth efficiencies were calculated by comparing DFAA uptake and bacterial production supported by the DFAA addition. In an incubation with a DFAA addition, the net uptake rate of DFAA was estimated from the decrease in primary amine concentrations (Fig. 5A), which is dominated by the DFAA pool (Kirchman et al. 1989). Bacterial production supported by the 

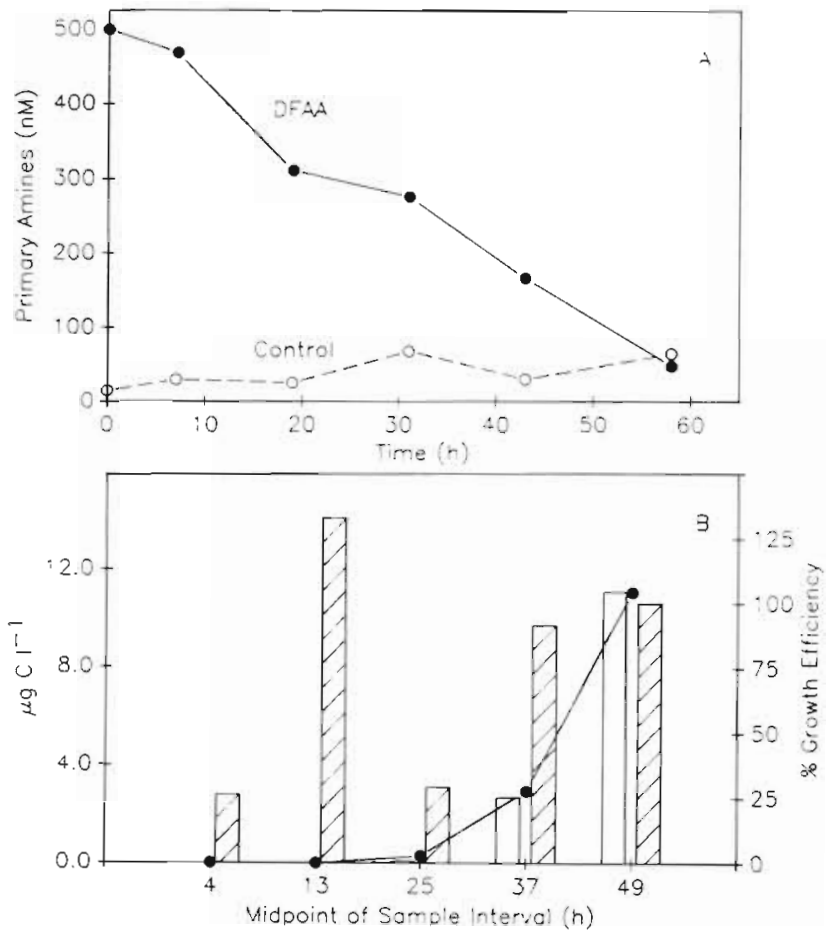

Fig. 5. Comparison of DFAA uptake (decrease in primary amine concentrations) and bacterial production supported by DFAA addition. (A) Primary amine concentration in incubation with $500 \mathrm{nM}$ addition of DFAA and in control; (B) DFAA uptake (hatched bars), bacterial production supported by DFAA addition (open bars), and \% growth efficiency (closed circles). Calculated from data in Fig. 3. Values are means of 2 replicates that differed by $<15 \%$

DFAA addition was estimated by subtracting the rate in unamended controls from that in DFAA-amended samples.

In the DFAA incubation, primary amine concentrations decreased immediately (Fig. 5A), indicating net uptake of DFAA during the entire experiment (Fig. 5B). In contrast, bacterial production supported by DFAA was not measurable for the first $31 \mathrm{~h}$ (Fig. 5B). Nearly all of the stimulation of ${ }^{3} \mathrm{H}$-thymidine incorporation, i.e. bacterial production, was observed in samples taken at 43 and $58 \mathrm{~h}$. Consequently, efficiencies of growth on the added DFAA were essentially zero during the first $31 \mathrm{~h}$ and increased to $104 \%$ at the end of the experiment ( $49 \mathrm{~h}$; Fig. 5B). The overall growth efficiency was $34 \%$ which is similar to the assimilation efficiency estimated using ${ }^{3} \mathrm{H}$-amino acids (e.g. Carlucci et al. 1986).

\section{DISCUSSION}

The DOM supply has been assumed to be important in regulating bacterial production - a conclusion based on the high correlation between bacterial production and primary production (Cole et al. 1988). However, the possibility remained that the high correlation was due to some hidden factor that covaried with rates of primary production (Cole et al. 1988). The results of this study suggest that the high correlation is because primary production, directly or indirectly, determines the supply of DOM. Addition of DOM, especially DFAA, increased bacterial production ( ${ }^{3} \mathrm{H}$-thymidine incorporation), and since abundance did not change, the observed increase must be due to an increase in bacterial growth rates (the production rate divided by bacterial abundance).

Although glucose alone sometimes stimulated ${ }^{3} \mathrm{H}$ thymidine incorporation, addition of DFAA clearly had the greatest impact on bacterial production (Table 1). Thus, it would be an oversimplification to conclude that heterotrophic bacteria were C-limited. Likewise, bacteria in the subarctic Pacific were not N-limited per se because addition of ammonium alone did not increase ${ }^{3} \mathrm{H}$-thymidine incorporation. Also, addition of organic $\mathrm{N}$, other than DFAA, stimulated ${ }^{3} \mathrm{H}$-thymidine incorporation to a lesser extent than observed with DFAA additions. Addition of ammonium plus DOM, sometimes greatly stimulated ${ }^{3} \mathrm{H}$-thymidine incorporation (e.g. Fig. 3A), but the data are insufficient to base any conclusions about possible synergistic effects between ammonium and DOM. Finally, $P$ is apparently not limiting bacterial production in the subarctic Pacific, because phosphate concentrations are relatively high (Anderson et al. 1977), and addition of DFAA alone stimulated bacterial production (this study).

The energetic advantage of using pre-formed amino acids probably explains why growth rates were higher with DFAA additions. In the laboratory, bacteria using amino acids have a higher growth rate compared with growth on glucose and ammonium (Ingraham et al. 1983) because cells save energy by avoiding amino acid biosynthesis (Payne \& Wiebe 1978). Because DFAA stimulated bacterial growth much more than glucose plus ammonium, bacterial growth in the subarctic Pacific appears to be energy-limited

Organic $N$, other than amino acids, is apparently not as important as DFAA in limiting bacterial growth rates. Protein probably did not have an immediate impact on ${ }^{3} \mathrm{H}$-thymidine incorporation because of the time needed to hydrolyze macromolecules before transport is possible. A mixture of alkylamines either did not stimulate ${ }^{3} \mathrm{H}$-thymidine incorporation or the effect was less than that observed with DFAA additions. Metabolism of alkylamines differs from that of amino acids as the latter can be used directly for protein synthesis whereas alkylamines have to be degraded before use as precursors in biomass production. Höfle (1984) also found that addition of putrescine or cadaverine (diamines) to seawater cultures did not 
stimulate bacterial growth. Bacteria mineralized these diamines to $\mathrm{CO}_{2}$ and none of the $\mathrm{C}$ was, apparently, used in biomass synthesis (Höfle 1984). In contrast, the assimilation efficiency of amino acids was high (Höfle 1984). The comparison between DFAA and alkylamine utilization (and other experiments with glucose and ammonium) indicates that the $\mathrm{C}: \mathrm{N}$ ratio of DOM (C: $\mathrm{N}_{\mathrm{s}}$ ) used by heterotrophic bacteria is not a factor in regulating growth rates of natural assemblages of bacteria, although $C: N_{s}$ is important in determining growth efficiencies (Billen 1984, Goldman et al. 1987).

The stimulation in bacterial production by the DFAA addition in these experiments was consistent with the known efficiency of bacteria utilizing amino acids. Overall growth efficiency was $34 \%$, which is similar to the assimilation efficiency estimated from ${ }^{3} \mathrm{H}$-amino acids (e.g. Carlucci et al. 1986). In addition, the increase in growth efficiency from 0 to $104 \%$ over time (Fig. 5B) is expected since cells increase their rate of protein synthesis (fueled by amino acid uptake) prior to increasing cell division ( ${ }^{3} \mathrm{H}$-thymidine incorporation) This uncoupling of ${ }^{3} \mathrm{H}$-thymidine incorporation from DFAA uptake occurs during a shift-up, the period during which the growth rate increases (Ingraham et al. 1983).

Because of the shift-up period, bacterial growth rates would not change immediately after a DOM input. In these experiments, the time after DOM additions, and prior to enhanced bacterial production, varied from $9 \mathrm{~h}$ to $>2 \mathrm{~d}$. In laboratory studies, the shift-up time is minutes for cells with generation times ranging from 0.5 to $7 \mathrm{~h}$ (Ingraham et al. 1983). In the subarctic Pacific, the average generation time of the entire bacterial assemblage ranged from 2 to $20 \mathrm{~d}$. So, both the incubation time and shift-up in these experiments were long compared to that of fast-growing cultures in the laboratory, but still less than the average generation time of the bacterial assemblage in the subarctic Pacific.

Bacterial abundance usually did not change over time, even though estimates of bacterial production indicated that abundance should have increased by as much as $50 \%$. Grazing probably prevented any increase in abundance. It is noteworthy that grazing rates apparently increased to match bacterial production even though DFAA additions stimulated production by as much as 4 -fold. In microcosm experiments in the subarctic Pacific, bacterial production varied up to 5fold dielly, while bacterial abundance changed $<20 \%$ (Wheeler et al. 1989). In other pelagic ecosystems, however, grazing may fail to match changes in bacterial production and in situ bacterial abundance can vary significantly over time (e.g. McManus \& Peterson 1988).

Another possible factor that influences bacterial growth is temperature (Pomeroy \& Deibel 1986). In the subarctic Pacific, incorporation rates of ${ }^{3} \mathrm{H}$-thymidine and ${ }^{14} \mathrm{C}$-leucine were stimulated $\left(Q_{10}\right.$ ca 2$)$ when the water temperature was raised $10^{\circ} \mathrm{C}(\mathrm{D}$. Kirchman \& $\mathrm{M}$. Simon unpubl. data). This suggests that bacterial growth was limited by temperature, although stimulation of DOM excretion cannot be ruled out. However, addition of organic compounds stimulated ${ }^{3} \mathrm{H}$-thymidine incorporation, even when the temperature was held constant. Also, rates of ${ }^{3} \mathrm{H}$-thymidine and ${ }^{14} \mathrm{C}$ leucine incorporation increased by 4 -fold from May to September, which was more than that expected $(50 \%$, based on $Q_{10}=2$ ) from the increase in temperature $(6$ to $12^{\circ} \mathrm{C}$ ). Despite a temperature effect on incorporation rates, the supply of DFAA appears to be the most important factor influencing bacterial growth rates in the subarctic Pacific.

The energetic advantage of utilizing amino acids over other $\mathrm{N}$ compounds implies that the supply of DFAA is likely to be important in regulating bacterial growth rates in all pelagic ecosystems. Also, other studies have shown that the affinity of heterotrophic bacteria for inorganic nutrients is greater than that of phytoplankton (Currie \& Kalff 1984, Suttle et al. in press), which suggests that bacterial growth rates would rarely be limited by the supply of ammonium and phosphate. The supply of DFAA, however, can be inadequate to support bacterial production and much of it can be supported by ammonium (Wheeler \& Kirchman 1986) and some unknown C. The use of different organic compounds affects the uptake of ammonium (Kirchman et al. 1989, in press) and growth efficiencies (Tempest \& Neijssel 1984), hence transfer of DOM to higher trophic levels via bacterial biomass. In short, the composition or quality of DOM as well as the rate of DOM supply is important in regulating bacterial processes in pelagic ecosystems.

Acknowledgements. This work was supported by a grant from the National Science Foundation (OCE 8614170). I thank R. G. Keil and P. A. Wheeler for their technical help and R. J. Geider, P. A. Wheeler and R. G. Keil for their comments on the manuscript. The paper also benefited from comments by 2 anonymous reviewers and discussions with C. Suttle.

\section{LITERATURE CITED}

Anderson, G. C., Lam, R. K., Booth, B. C., Glass, J. M. (1977). A description and numerical analysis of the factor affecting the processes of production in the Gulf of Alaska. University of Washington Department of Oceanography Special Report 76 (Ref. M-77-40), Seattle, Washington

Billen, G. (1984). Heterotrophic utilization and regeneration of nitrogen. In: Hobbie, J. E. and Williams, P. J. leB. (eds.) Heterotrophic activity in the sea. Plenum Press, New York

Billen, G., Fontigny, A. (1987). Dynamics of a Phaeocystisdominated spring bloom in Belgian coastal waters. II. Bacterioplankton dynamics. Mar. Ecol. Prog. Ser. 37: 249-257 
Billen, G., Joiris, C., Wijnant, J., Gillain, G. (1980). Concentration and microbiological utilization of small organic molecules in the Scheldt Estuary, the Belgian Coastal Zone of the North Sea and the English Channel. Est. cstl. mar Sci. 11: 279-294

Carlucci, A. F., Craven, D. B., Robertson, K. J., Henrichs, S. M. (1986). Microheterotrophic utilization of dissolved free amino acids in depth profiles of southern California borderland basin waters. Oceanol. Acta 9: 89-96

Chin-Leo, G., Kirchman, D. L. (1988). Estimating bacterial production in marine waters from the simultaneous incorporation of thymidine and leucine. Appl. envirl. Microbiol. 54: $1934-1939$

Cole, J. J., Findlay, S., Pace, M. L. (1988). Bacterial production in fresh and saltwater ecosystems: a cross-system overview. Mar. Ecol. Prog. Ser. 43: 1-10

Currie, D. J., Kalff, J. (1984). Can bacteria outcompete phytoplankton for phosphorus? A chemostat test. Microb. Ecol. 10: $205-216$

Fuhrman, J. A. (1987). Close coupling between release and uptake of dissolved free amino acids in seawater studied by an isotope dilution approach. Mar. Ecol. Prog. Ser. 37 $45-52$

Fuhrman, J. A., Azam, F. (1982). Thymidine incorporation as a measure of heterotrophic bacterioplankton production in marine surface waters: evaluation and field results. Mar Biol. 66: 109-120

Gardner, W. S., Chandler, J. F., Laird, G. A. (1989). Organic nitrogen mineralization and substrate limitation of bacteria in Lake Michigan. Limnol. Oceanogr. 34: 478-485

Goldman, J. C., Caron, D. A., Dennett, M. R. (1987). Regulation of gross growth efficiency and ammonium regeneration in bacteria by substrate $\mathrm{C}: \mathrm{N}$ ratio. Limnol. Oceanogr. 32: 1239-1252

Hobbie, J. E., Daley, R. J., Jasper, S. (1977). Use of Nuclepore filters for counting bacteria by fluorescence microscopy Appl envirl Microbiol. 33: 1225-1228

Höfle, M. G. (1984). Degradation of putrescine and cadaverine in seawater cultures by marine bacteria. Appl envirl Microbiol. 47: 843-849

Howarth, R. W (1988). Nutrient limitation of net primary production in marine ecosystems. A. Rev. Ecol. 19: 89-110

Ingraham, J. L., Maaløe, O., Neidhardt, F. C. (1983). Growth of the bacterial cell. Sinauer Assoc. Inc., Sunderland, Massachusetts

Jørgensen, N. O. G. (1987). Free amino acids in lakes: Concentrations and assimilation rates in relation to phytoplankton and bacterial production. Limnol. Oceanogr. 32: $97-111$

Jørgensen, N. O. G., Søndergaard, M., Hansen, H. J., Bosselmann, S., Riemann, B. (1983). Diel variation in concentration, assinilation and respiration of dissolved free amino acids in relation to planktonic primary and secondary production in two eutrophic lakes. Hydrobiologia 107: $107-122$

Kirchman, D. L., Ducklow, H. W., Mitchell, R. (1982). Estimates of bacterial growth from changes in uptake rates and biomass. Appl. envirl Microbiol. 44: 1296-1307

This article was presented by Dr S. Y Newell, Sapelo Island, Georgia. USA
Kirchman, D. L., K'nees, E., Hodson, R. E. (1985). Leucine incorporation and its potential as a measure of protein synthesis by bacteria in natural aquatic systems. Appl. envirl Microbiol 49: 599-607

Kirchman, D. L., Keil, R. G., Wheeler, P. A. (1989). The effect of amino acids on ammonium utilization and regeneration by heterotrophic bacteria in the subarctic Pacific. DeepSea Res. 36: 1763-1776

Kirchman, D. L. Keil, R. G., Wheeler, P. A. (in press). Carbon limitation of ammonium uptake by heterotrophic bacteria in the subarctic Pacific. Limnol. Oceanogr

Lee, S. Fuhrman, J. A. (1987). Relationship between biovolume and biomass of naturally derived marine bacterioplankton. Appl. envirl Microbiol. 53: 1298-1303

Martin, J. H., Fitzwater, S. E. (1988). Iron deficiency limits phytoplankton growth in the north-east Pacific subarctic. Nature, Lond. 331: 341-343

McManus, G. B., Peterson, W. T (1988). Bacterioplankton production in the nearshore zone during upwelling off central Chile Mar. Ecol. Prog. Ser. 43: 11-17

Meyer, J. L., Edwards, R. T., Risley, R. (1987). Bacterial growth on dissolved organic carbon from a blackwater river. Microb. Ecol. 13: 13-29

Miziorko, H. M., Lorimer, G. H. (1983). Ribulose-1,5-bisphosphate carboxylase-oxygenase. A. Rev. Biochem. 52: 507-535

Parsons, T R., Maita, Y., Lalli, C. M. (1984). A manual of chemical and biological methods for seawater analysis. Pergamon Press, Elmsford, New York

Payne, W. J., Wiebe, W. J. (1978). Growth yield and efficiency in chemosynthetic microorganisms. A. Rev. Microbiol. 32: 155-183

Pomeroy, L. R., Deibel, D. (1986). Temperature regulation of bacterial activity during the spring bloom in Newfoundland coastal waters. Science, N.Y 233: 359-361

Sieracki, M. E., Sieburth, J. McN. (1985). Factors controlling the periodic fluctuation in total planktonic bacterial populations in the upper ocean: comparison of nutrient, sunlight and predation effects. Mar. microb. Fd Webs 1. 35-50

Suttle, C. A., Fuhrman, J. A., Capone, D. G. (in press). Rapid flux and concentration dependent partitioning of ammonium in marine plankton communities. Limnol. Oceanogr.

Tempest, D. W., Neijssel, O. M. (1984). The status of $Y_{\text {ATP }}$ and maintenance energy as biologically interpretable phenomena. A. Rev. Microbiol. 38: 459-486

Wheeler, P. A., Kirchman, D. L. (1986). Utilization of inorganic and organic nitrogen by bacteria in marine systems. Limnol. Oceanogr. 31: 998-1009

Wheeler, P. A., Kirchman, D. L., Landry, M. R., Kokkinakis, S. A. (1989). Diel periodicity in ammonium uptake and regeneration in the oceanic subarctic Pacific: implications for interactions in microbial foodwebs. Limnol. Oceanogr. 34: 1025-1033

Wright, R. T., Coffin, R. B. (1984). Factors affecting bacterioplankton density and productivity in salt marsh estuaries. In: Current perspectives in microbial ecology, Klug, M. J., Reddy, C. A. (eds.) American Society for Microbiology, Washington, D.C., p. 485-494

Manuscript first received: August 23, 1989

Revised version accepted: January 11, 1990 